\title{
Memahami Lelangan Beksan Banjaransari melalui Elemen Musikal Karawitan
}

\author{
A.M. Hermien Kusmayati ${ }^{1}$ dan Raharja \\ Fakultas Seni Pertunjukan, Institut Seni Indonesia Yogyakarta
}

\begin{abstract}
Understanding Lelangan Beksan Banjaransari through Karawitan Musical Elements. Classical dance of Pakualaman palace of Yogyakarta was created by incorporating meaningful elements of motion, costume, storyline and music. Likewise with Lelangen Beksan Banjaransari excavated from Babad Segaluh. Problems arise in the community's efforts to understand the message contained in the dance work. Based on observations shows evidence, that the community does not have enough knowledge about dance music. This paper reveals through the musical and non-musical aspects needed. This method is also expected to be used as a basis to understand other dances.
\end{abstract}

Keywords: dance; Pakualaman; beksan Banjaransari; karawitan

\begin{abstract}
ABSTRAK
Karya tari klasik Pura Pakualaman Yogyakarta diciptakan dengan memasukkan unsur gerak, busana, alur cerita, dan musik pendukung yang sarat makna. Demikian pula dengan Lelangen Beksan Banjaransari yang digali dari Babad Segaluh. Permasalahan timbul pada upaya masyarakat untuk memahami pesan yang termuat dalam karya tari tersebut. Berpijak pada pengamatan yang dilakukan menunjukkan bukti, bahwa masyarakat belum memiliki pengetahuan yang cukup tentang karawitan tari. Tulisan ini mengungkap melalui aspek musikal dan non-musikal yang diperlukan untuk memahami tarian yang dimaksud. Cara tersebut, juga diharapkan dapat dipergunakan sebagai landasan untuk memahami tarian lainnya.
\end{abstract}

Kata kunci: tari; Pakualaman; beksan Banjaransari; karawitan

\section{Pendahuluan}

Fungsi dan peranan karawitan sering dijadikan sebagai materi dalam music discourse. Salah satu aspek yang menarik untuk diangkat sebagai topik adalah kedudukannya sebagai pendukung cabang seni terkait. Supanggah secara tegas menyatakan bahwa eksistensi karawitan tidak hanya dimanfaatkan sebagai pengiring (music accompaniment) (2007: 263). Karawitan pada sajian tari klasik Yogyakarta sering dianalogikan sebagai 'ruh' atau dapat diartikan sebagai kekuatan ekspresi. Benamou menyatakan bahwa musisi Jawa (pengrawit) mempergunakan sistem bahasa untuk mengkategorikan dan mengkarakteristikkan yang didengar dan yang dirasakan sehingga nilai estetika dari musik Jawa tersebut dapat diketahui
(Harwood, 2011: 78). Hal ini diperkuat dengan adanya temuan di lapangan yang menunjukkan adanya bukti atas pentingnya peranan musik tersebut. Segala aktivitas, upaya, dan kompetensi yang dituangkan para pemusik (pengrawit) dan vokalisnya (pesindhen atau penggerong) turut membangun suasana adegan, menghidupkan ekspresi pemain atau suatu karakter, memberi penekanan pada setiap detail gerakan ataupun sekedar gesture saja. Dalam hal ini, musik menjadi bagian dari ekspresi pemain musik yang diproduksi sebagai bentuk strategi ucapan (Sunardi, 2017). Permainan musik dapat tumbuh dari kebiasaan pengrawit yang akan membentuk kerangka perspektif, representatif, maupun tindakan pengrawit dalam bermusik (Prasetya, Haryono, \& Simatupang, 2011: 156). Artinya, sajian musik

\footnotetext{
1 Alamat korespondensi: Fakultas Seni Pertunjukan, Institut Seni Indonesia Yogyakarta. Hp.: 08122790935. E-mail: hermienkusmayati@gmail.com.
} 
yang diekspresikan dalam bentuk instrumentalia ataupun vokal mempunyai tugas yang tidak bisa dianggap ringan karena kecerdasan, kecakapan, dan keterampilan musikalitas seniman dapat diamati dan dinilai dari kemampuan garap musikalitas mereka (Irawan, Soedarsono, \& Simatupang, 2014: 19). Hal tersebut terjadi pula pada sajian Lelangen Beksan Banjaransari, sebuah repetoar yang digali dari sebuah kronik yang disebut Babad Segaluh. Motif-motif gerak dan musik pengiringnya menjadi ekspresi penciptanya (Indrayuda, 2015: 148). Setiap gerak dideskripsikan melalui elemenelemen dasarnya seperti bagian tubuh, irama, arah dan level (Astuti, 2010: 63-64). Tarian tersebut diciptakan dan masih dilestarikan hingga saat ini di lingkungan Pura Pakualaman Yogyakarta. Penari beksa, dalam hal ini, harus menguasai pathokan baku (the dance standarts) untuk tarian gaya Yogyakarta yang dikenal sebagai Joged Mataram atau beksan tersebut (Saearani, Simatupang, Soedarsono, \& Kusmayati, 2014: 135).

Permasalahan yang sering dihadapi masyarakat atas garap tari dan musik pengiringnya tersebut terkait dengan kegagalan upaya untuk memahami aspek musikal dan tarinya sebagai berikut. Pertama, upaya pemahaman unsur pembentuk musikal karawitan. Kedua, pemahaman terhadap tari melalui karawitan sebagai musik pendukungnya. Soedarsono menyebutkan bahwa musik merupakan partner tari yang tidak dapat dipisahkan (Sinaga, 2016: 166). Sementara masyarakat awam atau masyarakat yang belum memiliki pengetahuan yang cukup biasanya menganggap bahwa peranan karawitan pada sebuah sajian tari seolah-olah hanya dianggap sebagai ilustrasi. Oleh sebab itu, peranan dan fungsinya sering dikesampingkan. Dinamika yang digarap melalui kekayaan ragam gerak tarian, cara pengekspresian, dan perbedaan suasana pada masing-masing bagian tidak dapat dimengerti melalui ragam bentuk gending yang disajikan. Tema dan alur cerita tidak dapat dipahami melalui cakepan atau liriknya. Kedua kalimat terakhir menunjukkan adanya indikasi bahwa pokok permasalahannya terletak pada ketidakcukupan bekal pengetahuan mengenai karawitan.

Solusi dari permasalahan tersebut dapat dilakukan dengan memberi informasi dan pemahaman kepada masyarakat. Hal tersebut bertujuan agar memiliki pengetahuan yang cukup mengenai karawitan, dalam hal ini terkait fungsi dan peranannya sebagai musik pendukung pada Lelangen Beksan Banjaransari. Musikalitas atau garapnya dapat ditelaah melalui elemen pembentuk karawitan yang terdiri dari instrumentalia dan vokal. Sejauh pengetahuan penulis, permasalahan terkait musik pada Lelangen Beksan Banjaransari belum pernah dibahas dalam forum perbincangan secara resmi ataupun dijadikan sebagai topik penelitian sehingga materi ini masih orisinil.

\section{Musik Iringan Tari}

Karawitan dalam pengertiannya sebagai sebuah produk kreativitas musikal dapat disajikan secara mandiri. Istilah yang biasa dipergunakan untuk menyebutkan jenis sajian musiknya, yaitu klenengan (Atmadja, 2011: 52-53). Istilah lain yang sering dipergunakan oleh masyarakat di wilayah Yogyakarta adalah uyon-uyon. Supanggah menjelaskan bahwa klenengan atau uyon-uyon merupakan sajian karawitan mandiri yang tidak dikaitkan dengan kebutuhan atau keperluan kesenian lainnya (2007:109). Jenis musik yang dimaksud dapat dimainkan sebagai sajian mandiri, baik dalam format pertunjukan maupun bukan pertunjukan. Trustho mengungkapkan, untuk konteks yang lain, bahwa karawitan dapat disajikan dalam format berbeda. Contoh penerapannya yaitu untuk mendukung sajian seni terkait, misalnya: tari, wayang kulit, dan ketoprak. Eksistensi karawitan sangat menonjol dengan memberikan kontribusinya untuk mengisi ruang pertunjukan yang kosong, membangun suasana dramatik, dan memberi tekanan pada gerakan tertentu (2005: 16).

Tulisan ini difokuskan pada musik iringan tari (dance accompaniment music), yaitu produk kreativitas musikal yang diekspresikan melalui ricikan (alat musik) gamelan dan vokal (Suyatno, Tjokronegoro, Merthayasa, \& Supanggah, 2016: 571-572). Ada sebagian masyarakat karawitan yang memiliki preferensi untuk menggunakan istilah 'musik pendukung', sebagian masyarakat lainnya menggunakan istilah 'musik pengiring'. Penulis tidak akan memperdebatkan kedua istilah tersebut 
pada tulisan ini. Secara spesifik, penggunaannya lebih dikenal dengan istilah 'karawitan tari'. Oleh sebab itu, untuk membedakan jenis dan fungsi dengan musik lainnya akan disebut dengan istilah tersebut. Sejauh ini, jenis musik tersebut telah berkembang sejalan dengan keluasan ruang eksplorasi, kebebasan pengolahan pada ragam gerak, dan alur dramatik yang diciptakan oleh koreografer. Pendukung yang terdiri dari komposer dan para pelaku seni karawitan (pengrawit dan vokalisnya) turut memberikan andil yang signifikan. Kedalaman ekplorasi dan kompetensi masing-masing dipadukan untuk mendapatkan kualitas sajian yang terbaik. Gendhon dalam Roestopo mengungkapkan bahwa ekspresi tari dibantu dan seringkali diganti iringannya. Elemen pembentuknya terdiri dari beberapa unsur, yaitu: melodi, tempo, ritme/irama, dan pengolahan pada volumenya (1991: 10). Pernyataan tersebut mengandung makna bahwa karawitan tari mempuyai peranan yang dapat dianggap sejajar dengan tarinya.

Berkaitan dengan uraian pada paragraf sebelumnya, kutipan mengenai pernyataan Trustho dapat dipergunakan sebagai pijakan sekaligus pembatas makna 'kebebasan kreativitas' dalam ruang ekspresi iringan tari. Keterbukaan dan keluasan garap pada karawitan tari tidak dapat disamakan dengan ruang kreativitas pada sajian karawitan secara mandiri. Koherensi bunyi musikal dengan gerak tarinya digambarkan sebagai suatu upaya untuk saling memberikan pengaruh dan penyesuaian untuk mencapai titik keharmonisan keduanya. Selain itu, juga memberi pengaruh pada penataan struktur penyajian dan komposisi gendingnya (2007: 28-29).

Berpijak pada kutipan dan uraian sebelumnya didapatkan sejumlah keterangan, yaitu mengenai fleksibilitas penyajian, fungsi musikal, eksistensi, peranan, dan spesifikasi garap karawitan pada sajian tari. Beberapa aspek tersebut dipergunakan sebagai landasan untuk menganalisis garap karawitan. Hasilnya dipergunakan sebagai sarana untuk membuka wawasan masyarakat mengenai iringan tari. Pembicaraan pada tulisan ini difokuskan pada Lelangen Beksan Banjaransari koleksi Pura Pakualaman Yogyakarta sebagai objek.

\section{Bentuk dan Struktur Gending}

Permasalahan yang dibicarakan pada permulaan bagian ini mengenai 'bentuk gending'. Salah satu aspek bahasan dalam pengetahuan karawitan yang sangat penting untuk diketahui oleh masyarakat pemerhati karawitan, khususnya mengenai iringan tari. Tujuan pentingnya pengetahuan karawitan tersebut dikuasai agar mengerti dan memahami bahwa musik tersebut diciptakan oleh penata musik atau komposernya dengan menggunakan pijakan yang 'gumathok'. Artinya, sesuai dengan konvensi atau aturan tidak tertulis pada tradisi musik yang dimaksudkan. Namun dalam penataan gending terdapat tolok ukur estetika yang disebut dengan laras (Saepudin, 2015: 53; Widodo, 2015: 35; Widodo, Ganap, \& Soetarno, 2017). Repertoar karawitan tari gaya Yogyakarta biasa diciptakan dengan menggunakan satu atau susunan yang terdiri dari beberapa bentuk gending (medley).

Secara konvensional, bentuk gending disusun dan ditata dalam satuan metrik yang berukuran sama (Kriswanto, 2008: 91). Setiap bagian dituliskan pada notasi balungan gending dalam bentuk angka atau simbol tertentu yang bernilai empat 'sabetan' atau pukulan pada ricikan balungan (Grupe, 2015: 28-29). Tradisi dalam karawitan menyebut dengan istilah gatra. Gatra adalah lagu terkecil pada sebuah gending yang terbentuk dari serangkaian nada atau bukan nada yang dituliskan dengan simbol tertentu. Rangkaian gatra yang ditata dengan jumlah tertentu dan dilengkapi tabuhan pada ricikan penanda strukturnya (kethuk, kempyang, kenong, kempul, siwukan, dan gong) disebut 'gending'. Supanggah memberi penjelasan tentang nama bentuk gending, di antaranya adalah lancaran, srepegan, sampak, ayak-ayak, kemuda, ketawang, ladrang, dan bentuk gending berskala alit (kecil), tengahan (menengah), dan ageng (besar) (2007: 117-118).

Bentuk gending, lancaran, yang disebutkan paling awal dikategorikan sebagai komposisi lagu paling kecil. Setiap satu putaran berisi delapan sabetan (pukulan) pada ricikan balungan (slentem atau ricikan saron) dan diakhiri dengan gong suwukan/siyem (gong berukuran sedang) atau 
gong ageng (berukuran besar). Ricikan penanda atau sering disebut instrumen kolotomik mengisi ketukan berat ringan dan penyela di antara keduanya. Penataan tabuhan masing-masing ricikan-nya, bila dimainkan akan terdengar seperti perputaran metrik (cyclic meter). Pola permainannya menunjukkan struktur sebuah gending. Berikut ini adalah skema untuk menjelaskan bentuk dan struktur gending lancaran.

Penjelasan melalui gambar 1 menunjukkan adanya pola kreativitas musikal untuk menata jumlah ketukan, gatra dan permainan pada ricikan kolotomik. Struktur gending, apabila dicermati melalui ricikan kolotomiknya, terlihat seperti sebuah pola tabuhan yang dibangun dengan teknik imbalimbalan (interlocking). Pola tersebut merupakan pola tabuhan yang dimainkan minimalnya pada dua ricikan dengan melodi atau pattern (patron) secara teratur dan bergantian. Bagian yang ditandai dengan tanda titik merupakan posisi untuk menempatkan tabuhan ricikan balungan, misalnya: slentem dan keluarga saron. Bentuk gending yang paling sederhana ini menjadi pijakan untuk mengembangkan bentuk gending lainnya. Hal itu dilakukan dengan melipatgandakan jumlah (multiple), mengulur (expand) dan mengubah penempatan tabuhan ricikan kolotomiknya.

Kreativitas penciptaan dengan mengembangkan jumlah tabuhan dan struktur yang berpijak pada gending tersebut bisa berkembang menjadi bentuk gending lainnya, yaitu: bubaran (16 sabetan per gongan), ketawang (16 sabetan per gongan), dan ladrang (32 sabetan per gongan). Penciptaan

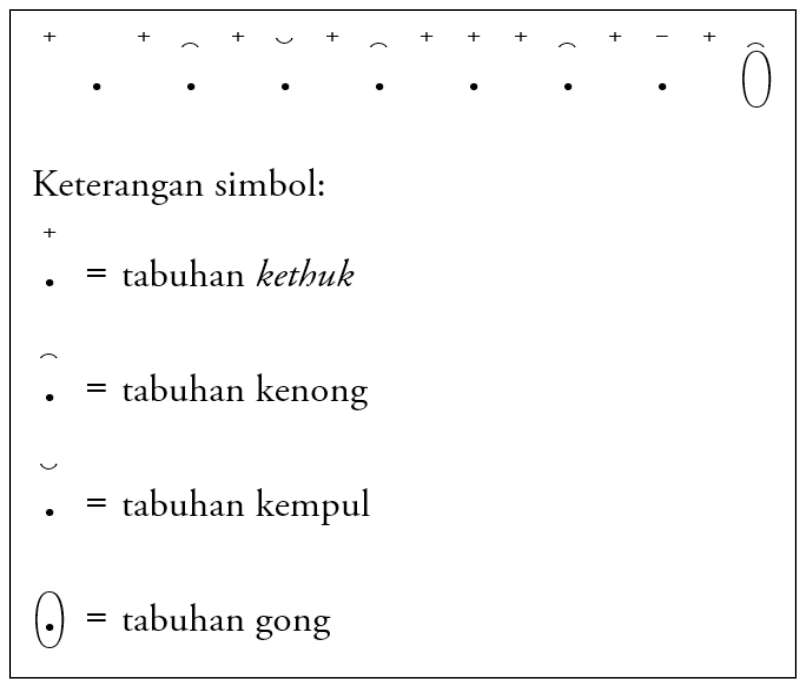

Gambar 1. Bentuk dan struktur lancaran. gending yang lebih besar juga dilakukan dengan menggunakan cara tersebut. Oleh sebab itu, didapatkan gending dengan 64, 128, 256, dan 512 sabetan per gongan. Pengecualiannya terdapat pada penghilangan tabuhan ricikan kempul. Bentuk gending yang lebih besar dari ladrang tidak menggunakan ricikan tersebut. Jadi, pemahaman mengenai jumlah sabetan dan struktur tabuhan pada ricikan kolotomik dapat dipergunakan untuk mengidentifikasi semua bentuk gending, termasuk iringan Lelangen Beksan Banjaransari berikut ini.

\section{A. Gending Runtut}

$$
\begin{aligned}
& \text { A1. Merong } \\
& \text {..1. } 116523532121 \\
& \text {..1. } 116523532121 \\
& 55 \ldots 5535 i 6563565 \\
& 23532126.2 .1 .6 .5 \\
& .6 .5
\end{aligned}
$$

A2. Ngelik:

$$
\begin{array}{llll}
66 \ldots & 6656 & 23 \dot{3} i & 653 \hat{5} \\
66 \ldots & 6656 & 23 \dot{i} & 653 \hat{5} \\
55 \ldots & 5535 & 1656 & 356 \hat{5} \\
2353 & 2126 & .2 .1 & .6 . \hat{5}
\end{array}
$$

$$
\begin{array}{rlll}
\text { A3. Inggah: } & & \\
.2 .1 & .6 .5 & .6 .5 & .2 .1 \\
.2 .1 & .6 .5 & .6 .5 & .2 .1 \\
.6 .5 & .6 .5 & .1 .6 & .3 .5 \\
.2 .1 & .2 .6 & .2 .1 & .6 .5
\end{array}
$$

Racikan atau susunan gending pada Lelangen Beksan Banjaransari diawali dengan gending Runtut. Racikan tersebut terdiri dari 64 sabetan balungan yang disusun dalam bentuk gatra. Masing-masing gatra berisi 4 sabetan sehingga terdapat 16 gatra. Dari notasi yang ditulis tampak bahwa gending Runtut terdiri dari dua bagian, yaitu: merong dan inggah (istilah karawitan gaya Surakarta) atau dados dan ndhawah (istilah karawitan gaya Yogyakarta). Pura Pakualaman menganut karawitan gaya Surakarta sehingga penulisannya menggunakan istilah karawitan gaya Surakarta pula. 
Penulisan judul secara lengkap dengan menyertakan keterangan lainnya, yaitu 'kethuk kalih kerep minggah sekawan, laras slendro pathet sanga. Kethuk kalih kerep minggah sekawan adalah kethuk dua kerap meningkat menjadi empat, sedangkan laras slendro pathet sanga adalah laras slendro pathet (modus) sembilan. Keterangan pada judul memberi informasi mengenai bentuk gendingnya, yaitu mengenai jumlah tabuhan pada ricikan kethuk. Merong atau bagian utama memiliki dua tabuhan kethuk pada setiap baris. Akhir masing-masing bagian ditandai dengan satu tabuhan kenong. Terkait dengan strukturnya, ricikan kethuk ditabuh pada akhir gatra pertama dan ketiga. Selanjutnya, bagian inggah memiliki empat tabuhan kethuk pada setiap kenongannya. Perbedaan dengan bagian merong terletak pada penempatan tabuhannya, yaitu pada hitungan kedua pada setiap gatra. Aturan mengenai jumlah dan penempatan tabuhan kethuk, jumlah kenongan, serta jumlah sabetan balungan pada setiap putaran gong dapat dipergunakan untuk mengidentifikasi suatu bentuk gending.

Racikan selanjutnya adalah gending berbentuk ladrang. Adapun notasi balungan gending dan penjelasannya adalah sebagai berikut.

\section{B. Ladrang}

$\begin{array}{llllllll}1 & 6 & 1 & 2 & 3 & 2 & 1 & 6 \\ 5 & 5 & 6 & \grave{i} & 2 & i & 6 & 5 \\ i & 6 & 5 & 6 & 5 & 2 & 1 & 6 \\ 3 & 5 & 3 & 2 & 1 & 6 & 3 & \overline{5}\end{array}$

Bentuk gendingnya tertulis sebagai gending ladrang. Penjelasan mengenai maknanya belum bisa ditemukan hingga saat ini. Komposisi lagunya terdiri dari tiga puluh dua sabetan balungan pada setiap putaran gong. Kenong menjadi penanda pada akhir lagu yang terdiri dari dua gatra. Ricikan kethuk ditabuh pada hitungan kedua dan keenam pada setiap kenongan. Keterangan mengenai jumlah tabuhan kethuk tidak dituliskan pada judul lagu seperti gending Runtut karena tidak ada perbedaan jumlah ketika dimainkan pada tingkatan irama lainnya, yaitu: irama tanggung (irama I), irama dados (irama II), irama wiled (irama III) dan irama rangkep (irama $I V$ ). Ricikan kempul ditabuh pada akhir gatra ketiga, kelima, dan ketujuh. Secara mudah, untuk mengidentifikasi bentuk gending ini dapat dilakukan dengan memperhatikan jumlah tabuhan kethuk pada setiap kenongan, tabuhan kempul (pada gatra 3, 5, dan 7), jumlah sabetan balungan pada setiap gongan.

Gending selanjutnya berbentuk ketawang yang berjudul Mijil. Adapun notasi balungan gending dan penjelasannya adalah sebagai berikut.

\section{Ketawang Mijil}

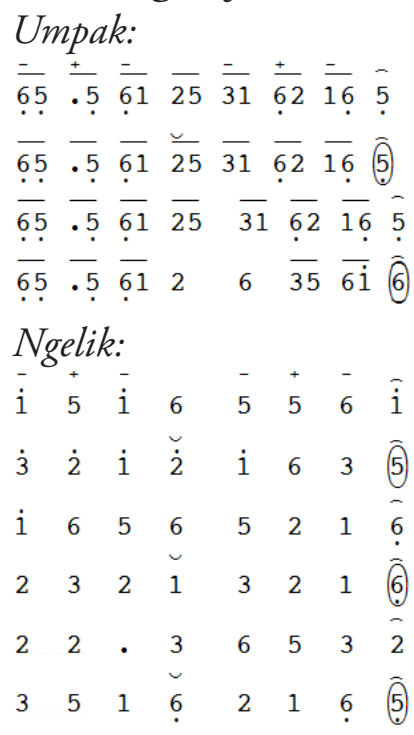

Ketawang Mijil adalah bentuk gending ketiga pada susunan iringan tari Bedhaya Banjaransari. Berpijak pada jenisnya tersebut, komposisi lagu tersebut termasuk dalam kategori gending sekar, gending yang sumber kreativitas garapnya menggunakan tembang atau sekar macapat, dalam hal ini adalah Mijil. Satu putaran gong berisi 16 sabetan pada ricikan balungan yang dibagi dalam gatra, sehingga terdapat 4 grup pada satuan tersebut. Ricikan kolotomik yang dipergunakan dan struktur tabuhannya sama dengan kenongan pertama dan keempat pada gending yang berbentuk ladrang. Komposisi ketawang Mijil terdiri dari dua bagian, yaitu: umpak dan ngelik. Kata umpak dalam bahasa Jawa diartikan sebagai fondasi. Analoginya, seperti sebuah konstruksi bangunan, umpak adalah bagian utama yang menjadi landasan untuk meletakkan bagian lainnya, dalam hal ini adalah ngelik.

\section{Vokal, Cakepan (Lirik) dan Tata Garap Penyajian Gendingnya}

Cakepan atau lirik lagu pada karawitan tari merupakan lapis kedua setelah unsur musikal 
yang diungkapkan melalui gamelannya. Banyak informasi bisa didapatkan melalui cakepannya. Oleh sebab itu, kompetensi seseorang sangat diperlukan untuk dapat mengerti dan memahaminya. Sejauh pengamatan penulis, ada beberapa kendala yang dihadapi masyarakat untuk mengetahui tema, alur cerita, dan makna sebuah tarian melalui cakepan lagunya. Adanya kesulitan pada upaya yang dilakukan dapat mengakibatkan timbulnya kegagalan pada proses pemahaman.

Kemungkinan terjadinya kegagalan disebabkan oleh beberapa faktor sebagai berikut. Pertama, ketiadaan waktu atau kesempatan untuk mendengarkan cakepan secara cermat. Permasalahan ini dapat dikaitkan dengan keterbatasan kemampuan otak manusia untuk mengolah berbagai informasi secara simultan. Pembicaraan ini berkaitan dengan tiga elemen di dalamnya, yaitu: gerakan tari, lagu/instrumentalia, dan cakepannya. Selain itu, keindahan busana penari dan kondisi pribadi masing-masing penari atau unsur lain yang tidak disebutkan menjadi faktor penyebab terpecahnya konsentrasi penonton. Kedua, tidak dapat mendengarkan cakepan dengan jelas. Hal ini mungkin saja terjadi karena teknik penyuaraan vokalis karawitan yang tidak atau kurang mendukung. Vokalis putri menggunakan teknik penyuaraan berkualitas nasal (suara hidung) dan rata-rata berada pada ambah-ambahan tengah (register standar) dan dhuwur (tinggi). Akibatnya, hal tersebut dapat mengganggu teknik pelafalan cakepannya. Selain itu, kurang jelasnya cakepan juga dapat disebabkan oleh kualitas akustik ruangan yang tidak bagus. Permasalahan dapat berkembang lagi bila tidak didukung dengan sound system yang memadai. Ketiga, tidak mengetahui makna cakepannya sehingga tidak dapat mengikuti alur ceritanya. Kurangnya bekal pengetahuan tentang bahasa yang dipergunakan dapat menjadi penyebab timbulnya masalah ini. Keempat, adanya kecenderungan untuk menikmati rasa gending atau alunan melodi vokal karawitan daripada mencermati cakepannya. Akibatnya, masyarakat hanya memahami suasana adegan melalui ekspresi musikal dari alunan vokal atau instrumentalianya.

Upaya pemahaman tema dan alur cerita pada Beksa Banjaransari dapat dilakukan dengan mencermati cakepan vokalnya. Penyajiannya diawali dengan pathetan slendro sanga wantah yang dalam tradisi wayang disebut sulukan, vokal yang dilantunkan secara tunggal oleh dalang. Perbedaannya terletak pada cara penyajian yang dilakukan secara instrumentalia. Lagu yang dimaksudkan pada pembicaraan ini dimainkan dalam irama bebas (secara melismatik). Fungsinya adalah untuk membingkai masing-masing ruang pengadegan. Sajian wayang kulit semalam suntuk atau uyon-uyon dibagi menjadi enam bagian yang diatur menurut pathet masing-masing. Pathetan dipergunakan untuk membangun suasana dengan pengaturan dan pembagian tugas nada pada lagunya. Salah satu isyarat gending menyajikan pathetan apabila gending diawali dengan bawa (Suyoto, Haryono, \& Hastanto, 2015: 37).

Seusai bagian tersebut dilanjutkan dengan vokal karawitan yang dilantunkan oleh vokalis pria secara tunggal (solo). Adapun notasi lagunya adalah sebagai berikut.

Bawa Sekar Ageng Banjaransari, lampah 19, pedhotan 6, 6, 7, laras slendro pathet sanga

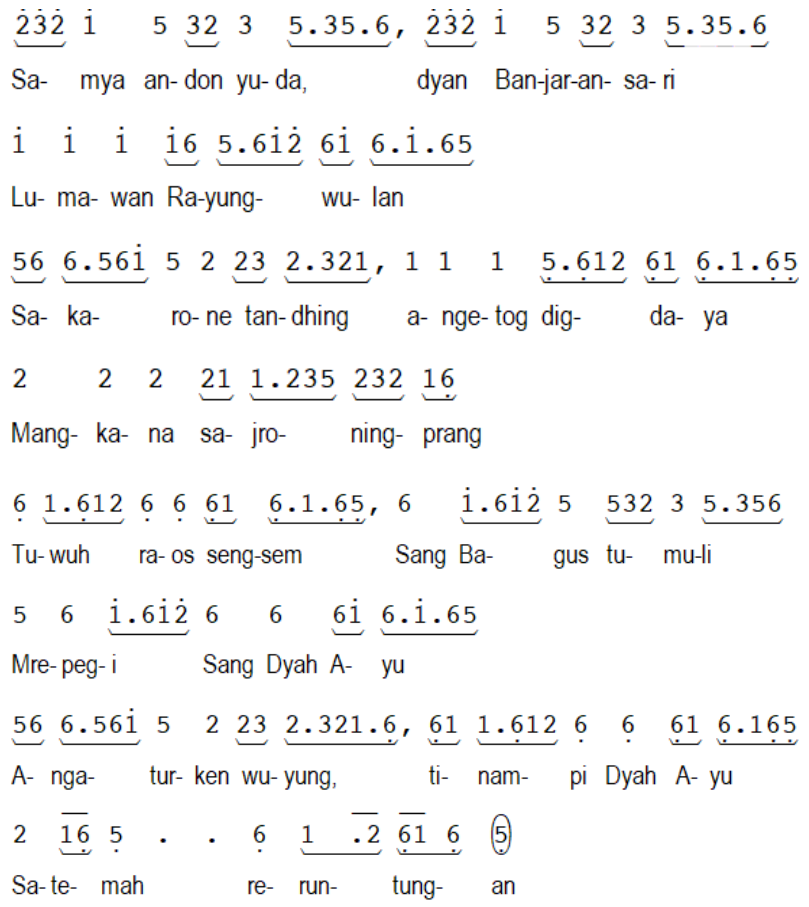

Bagian bawa, dilantunkan dengan diiringi tabuhan ricikan gender barung. Teknik tabuhan dan lagu yang diterapkan sangat sederhana dan hanya terdiri dari dua jenis. Pertama, disebut dengan istilah 'thingthingan', artinya membunyikan satu nada atau bila dilakukan secara beruntun harus 
berjeda waktu yang cukup antara nada yang satu dengan lainnya. Kedua, disebut 'nggrambyang', yaitu memainkan suatu bentuk lagu yang pendek dengan irama bebas. Tujuannya adalah untuk menjaga agar pelantunan bawa tidak terlepas dari larasan gamelannya. Cara melagukannya dilakukan secara melismatik atau berirama bebas. Bawa sekar ageng Banjaransari, lampah 19, pedhotan 6, 6, 7, laras slendro pathet sanga hanya dilantunkan sekali. Penyajiannya dimulai setelah musik pembuka berupa pathetan, yaitu suatu jenis lagu pada tradisi wayang yang disajikan secara instrumentalia. Jenis vokal yang dilantunkan adalah Bawa Sekar Ageng yang berjudul Banjaransari. Berikut ini adalah cakepan dan terjemahan untuk menjelaskan muatan di dalamnya.

Bawa Sekar Ageng Banjaransari, lampah 19, pedhotan 6, 6, 7, laras slendro pathet sanga

Samya andon yuda, Dyan Banjaransari,

Lumawan Rayungwulan

Sakarone tandhing, angetog digdaya,

Mangkana sajroning prang

Tuwuh raos sengsem, Sang Bagus tumuli,

Mrepegi Sang Dyah Ayu

Angaturken wuyung, tinampi Dyah Ayu,

Satemah areruntungan

Terjemahan:

Terlibat dalam peperangan, Sang Banjaransari

Melawan Rayungwulan

Keduanya bertanding, mengeluarkan kesaktiannya

Demikianlah dalam peperangan

Timbul rasa simpati, Sang rupawan kemudian

Menghampiri Sang Puteri rupawan

Menyampaikan rasa cinta, diterima Sang Puteri rupawan

Akhirnya berdampingan

(Terjemahan oleh Raharja)
Bagian vokal bawa dapat dianggap sebagai sebuah prolog sekaligus menjadi abstraksi dari keseluruhan alur cerita pada Lelangen Beksan Banjaransari. Oleh sebab itu, pemahaman tentang muatan pada tarian tersebut dapat dimulai dari bagian bawa. Jenis vokal pembuka merupakan salah satu dari beberapa jenis vokal karawitan. Ciri khas yang mengikat terdapat pada aturan lampah dan pedhotan. Kata 'lampah' menunjukkan jumlah keseluruhan suku kata dalam satu gatra, sedangkan kata 'pedhotan' menunjukkan 'pemutusan' yang berfungsi sebagai tempat pemberhentian untuk menghela nafas. Adapun angka 6, 6, 7 adalah jumlah silabel pada masing-masing bagian. Salah satu sebagai contohnya adalah gatra (baris) pertama, yaitu: 'samya andon yuda' berisi 6 suku kata, 'Dyan Banjaransari' berisi 6 suku kata, dan 'lumawan Rayungwulan'berisi 7 suku kata. Akumulasi jumlah suku kata $6+6+7$ menunjukkan lampah-nya, yaitu 19.

Cakepan pada bagian bawa menceritakan pertemuan dua figur, yaitu Raden Banjaransari dan Dewi Rayungwulan. Pertemuan keduanya menimbulkan perselisihan dan perkelahian. Keterangan tersebut terdapat pada gatra pertama dan kedua. Selanjutnya, gatra berikutnya menceritakan rasa simpati Raden Banjaransari pada saat melawan Rayungwulan. Gatra yang terakhir mengungkapkan perjalanan asmara yang berlanjut pada perkawinan keduanya. Terdapat sedikit perbedaan pada cara penyajian bagian gatra terakhir, yaitu dilantunkan secara berirama. Tujuannya adalah untuk mempermudah tabuhan ater-ater kendang dan menentukan laya (tempo) untuk memasuki bagian selanjutnya, yaitu gending Runtut. Notasi 1 adalah notasi balungan gending dan vokal pada bagian tersebut.

Notasi 1. Notasi balungan gending dan vokal pada bagian gending Runtut.

\section{Umpak:}

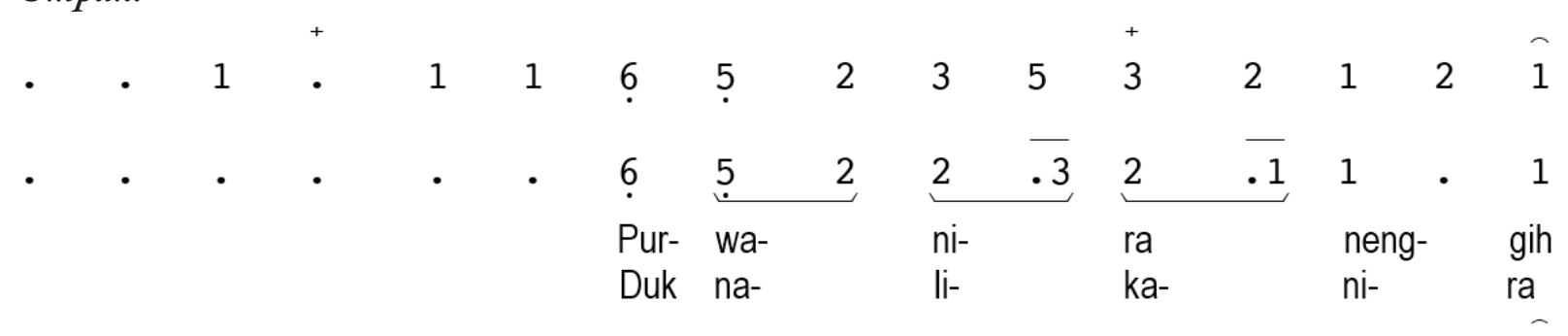




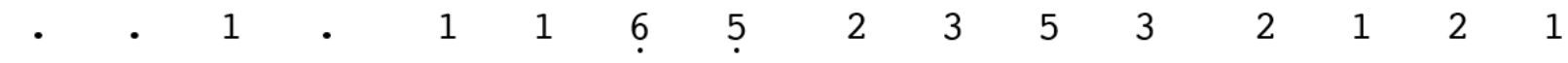

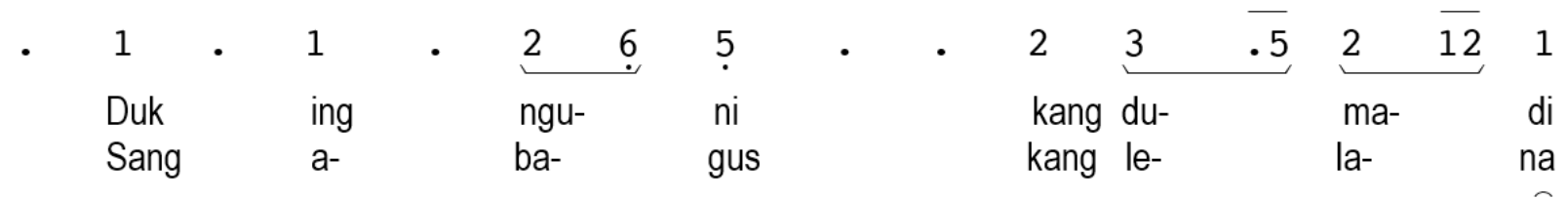

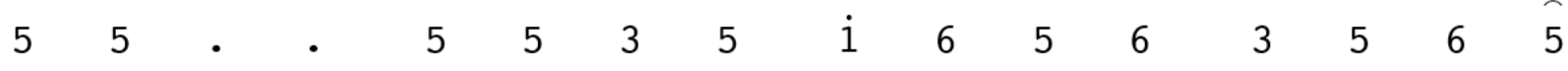

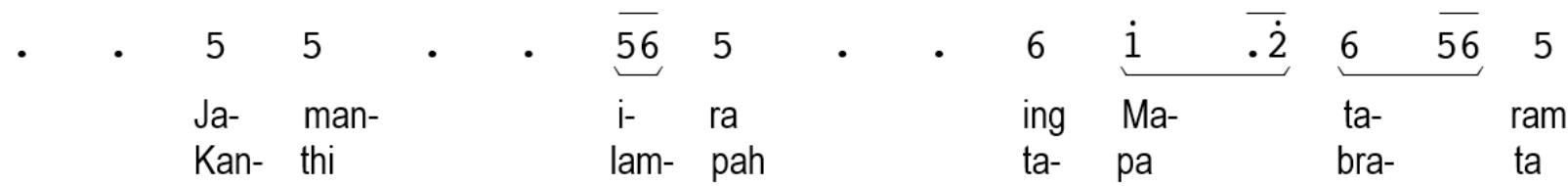

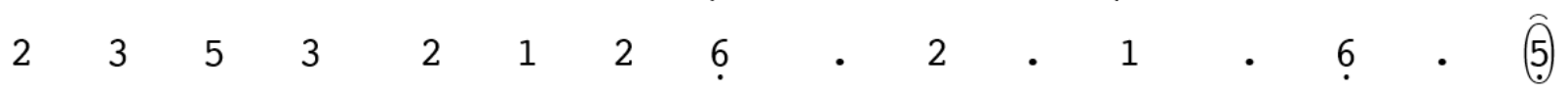

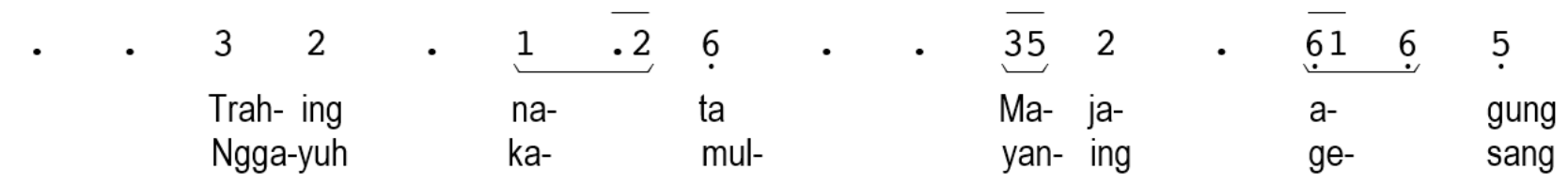

Ngelik:

Trah- ing
Ngga-yuh

ka- mul-

yan- ing

sang

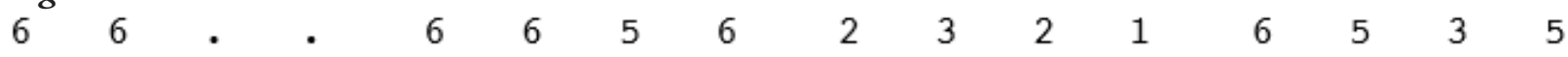

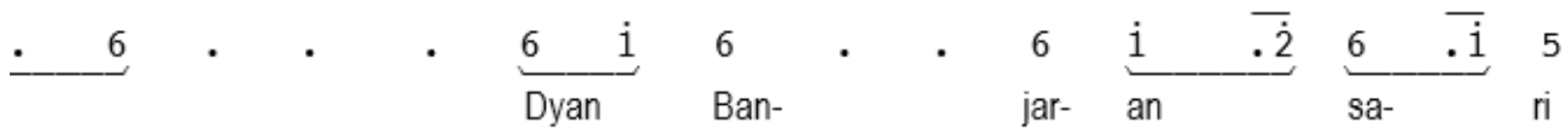

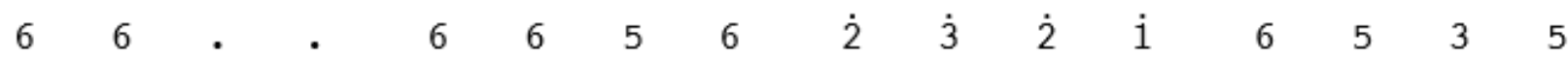

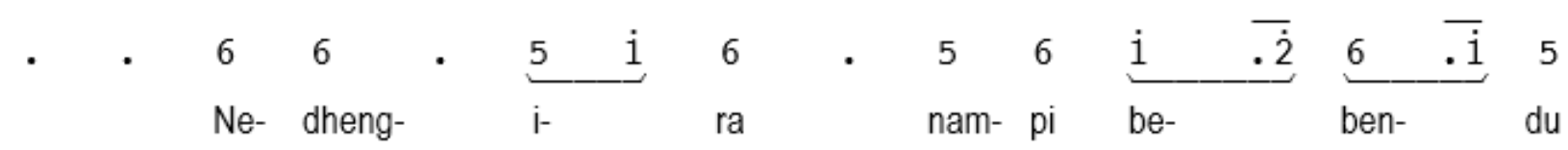

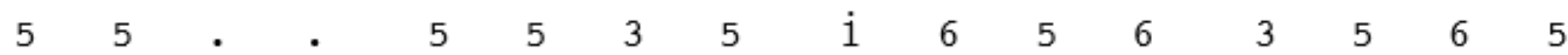

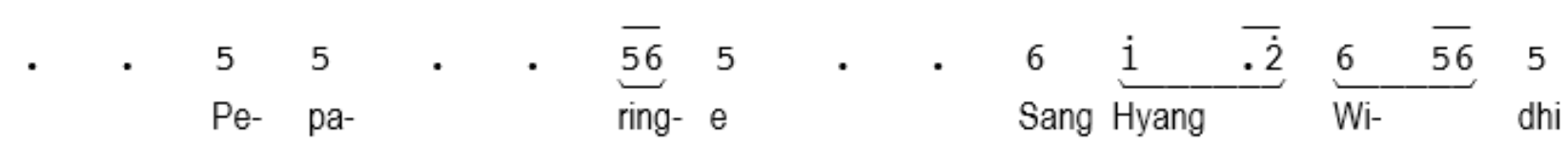

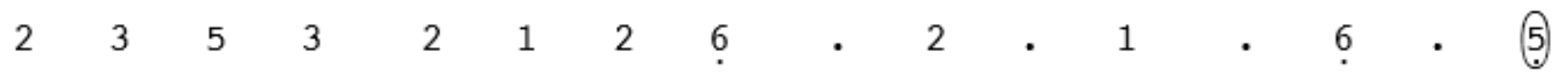

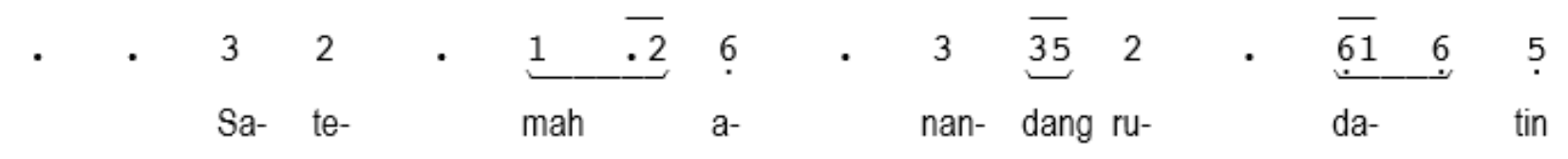

$\begin{array}{rlllllllllllllll}\cdot & 1 & \cdot & 1 & 1 & 6 & 5 & 2 & 3 & 5 & 3 & 2 & 1 & 2 & 1\end{array}$

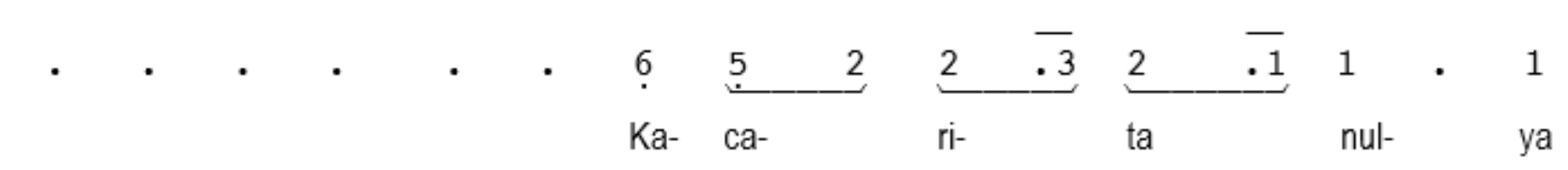

$\begin{array}{rlllllllllllllll}\cdot & \cdot & 1 & \cdot & 1 & 1 & 6 & 5 & 2 & 3 & 5 & 3 & 2 & 1 & 2 & 1\end{array}$

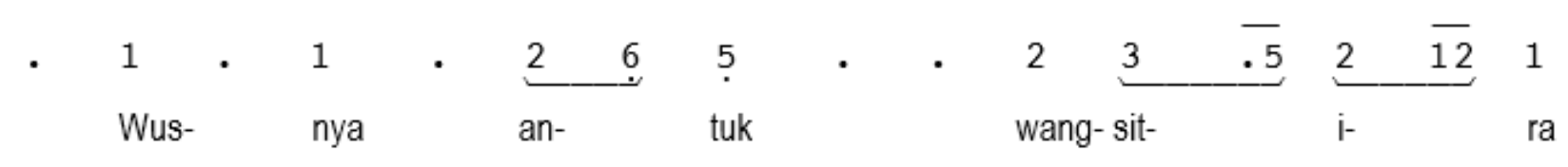




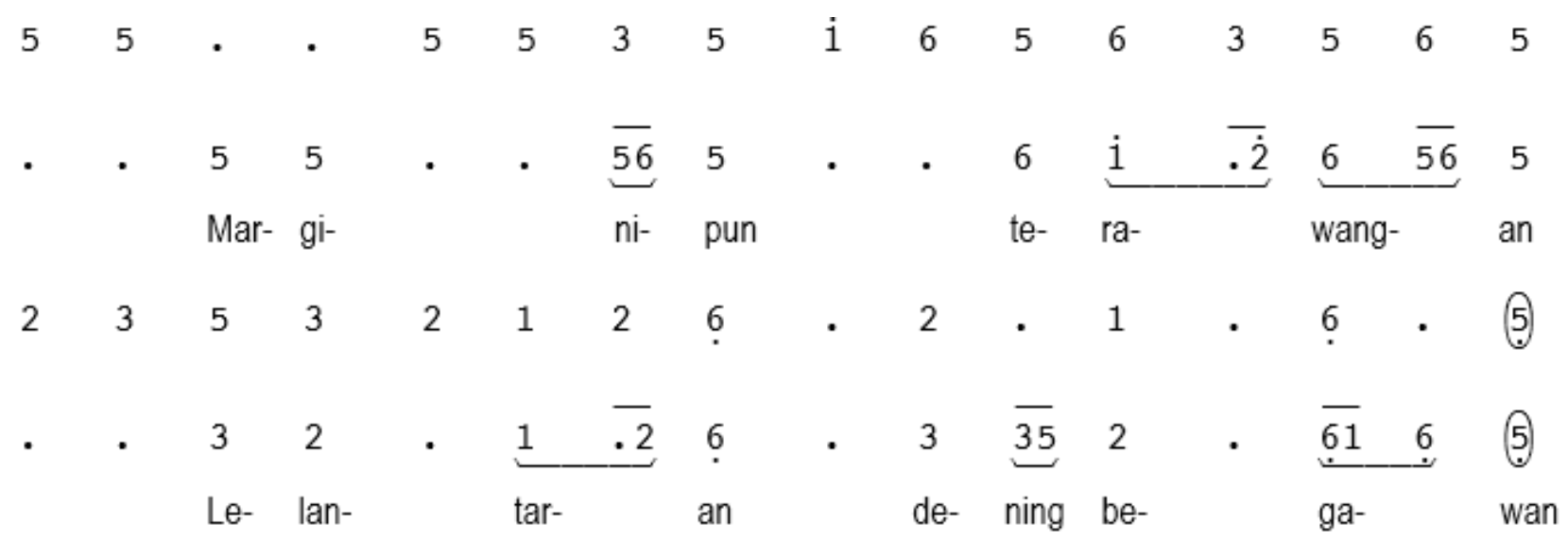

Vokal gerongan pada merong gending Runtut adalah jenis yang berbeda dengan bawa, baik pada bentuk dan cara penyajiannya. Bagian tersebut dilantunkan secara koor oleh vokalis pria dan wanita secara unison. Berikut ini adalah cakepan lagu beserta penjelasannya.

Purwakanira nenggih

Duk ing nguni kang dumadi

Jamanira ing Mataram

Trahing nata Maja Agung

Duk nalikanira Sang abagus kang lelana

Kanthi lampah tapa brata

Nggayuh kamulyaning gesang

\section{Nedhengira nampi bebendu \\ Peparinge Sang Hayang Widhi \\ Satemah anandang rudatin \\ Kacarita nulya \\ Wusnya antuk wangsitira \\ Marginipun terawangan \\ Lelantaran dening Begawan}

Terjemahan:

Permulaannya yaitu

Jaman dahulu yang terjadi

Pada jaman Mataram

Keturunan Bangsawan Maja Agung

Ketika Sang Rupawan berkelana

Dengan bertapa

Mendapatkan kemuliaan hidup

Ketika menerima bencana

Pemberian Tuhan

Kemudian mengalami kesusahan

Diceritakan kemudian

Setelah menerima petunjuknya

Perjalanannya menjadi jelas

Atas bantuan (seorang) begawan

(Terjemahan oleh Raharja)
Merong gending Runtut terdiri dari dua 'cengkok'. Pengertian cengkok pada pembicaraan ini adalah perjalanan lagu yang dibingkai dalam satu putaran gong. Bagian A merupakan lagu utama dan $\mathrm{B}$ adalah bagian ngelik sebagai variasi atau pengembangan ragam lagu. Pola penyajiannya dilakukan dengan urutan A1, A2, B, dan kembali lagi pada A1. Cakepan yang terdapat pada dua ulihan pertama menceritakan adanya sosok yang bernama Raden Banjaransari pada zaman Mataram, seorang bangsawan dari Maja Agung yang sedang menjalani laku prihatin, yaitu upaya spiritual untuk mendapatkan kemuliaan hidupnya. Ulihan ketiga dan empat menceritakan permasalahan yang dihadapi. Segala sesuatu menjadi terbuka dan jelas setelah terjadi pertemuan dengan seorang pendeta yang menjadi bagian dari pencerahan.

Berpijak pada terjemahan cakepan-nya, alur cerita pada bagian tersebut menceritakan kisah perjalanan hidup Raden Banjaransari. Perjalanan gending dilanjutkan ke bagian inggah. Berikut ini adalah cakepan gerongan pada bagian tersebut.

Inggah:

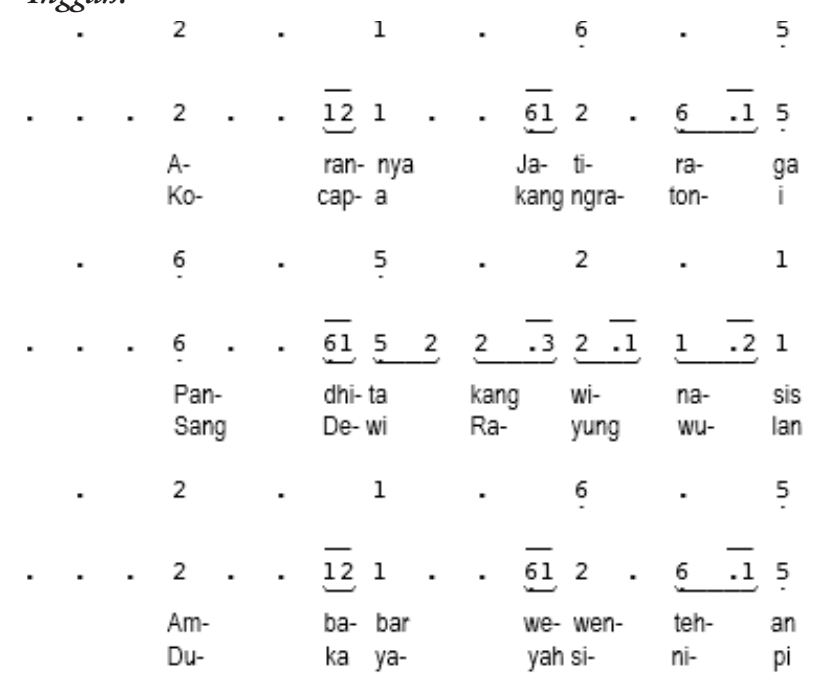




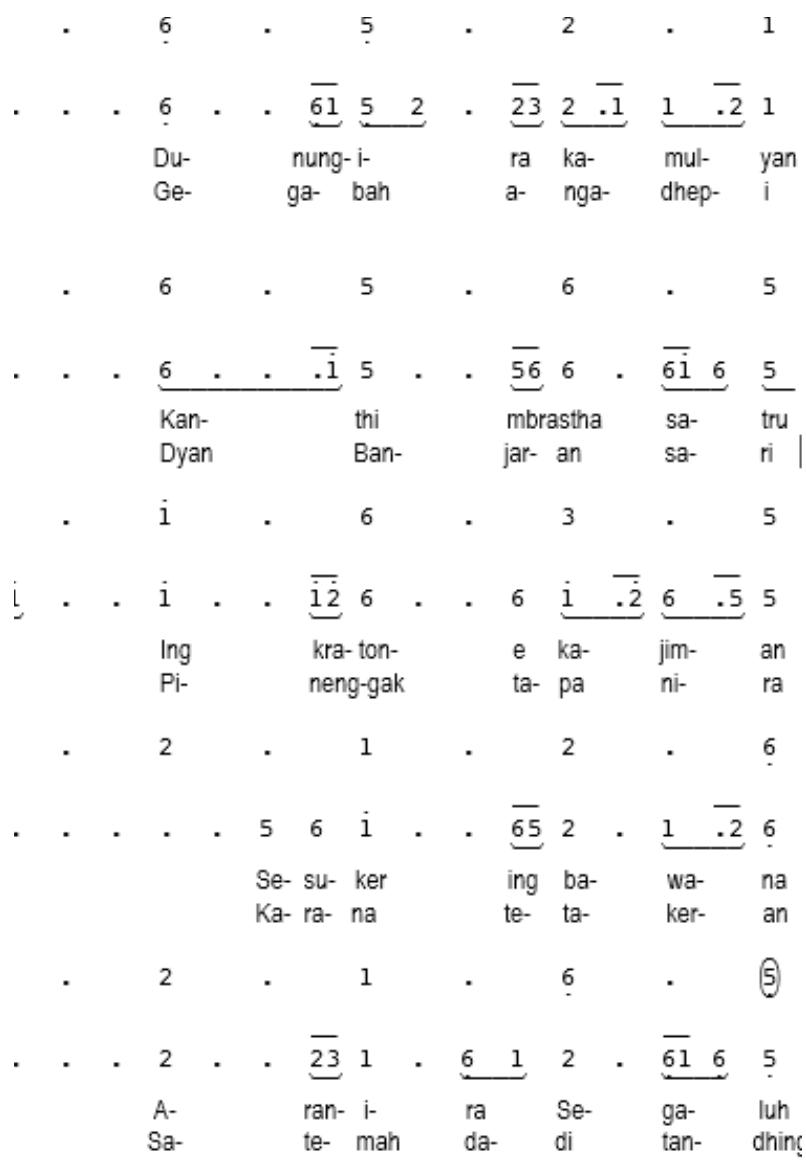

Bagian kedua pada gending Runtut biasa disebut sebagai inggah gending. Biasanya, pada mayoritas gending, kelanjutan lagunya dikembangkan dari bagian merong. Bagian tersebut tidak dimainkan pada irama wiled dan di-ciblon-kan (permainan pada kendang berukuran sedang), tetapi digarap dengan kendang setunggal. Perbedaan dengan bagian merong terletak pada pola tabuhan ricikan balungan, yaitu nibani atau memberi penekanan pada rasa seleh-nya saja. Inggah gending Runtut dilengkapi dengan vokal yang digubah untuk dua ulihan (putaran gong). Cara penyajiannya sama dengan sebelumnya, yaitu secara koor. Berikut ini adalag cakepan dan penjelasan mengenai isinya.

\section{Arannya Jatiraga}

Pandhita kang winasis

Ambabar wewentehan

Dunungira kamulyan

Kanthi mbrastha satru

Ing kratone kajiman

Sesukering bawana

Aranira Segaluh

$$
\begin{aligned}
& \text { Kocapa kang ngratoni } \\
& \text { Sang Dewi Rayungwulan } \\
& \text { Duka yayah sinipi }
\end{aligned}
$$

Gegabah angadhepi

Dyan Banjaransari

Pinenggak tapanira

Karana tetakeran

Satemah dadi tandhing

Terjemahan:

Namanya Jatiraga

Pendeta yang pandai

Membeberkan secara jelas

Letaknya kemuliaan

Dengan memberantas musuh

Di kerajaan bangsa jin

Pengganggu dunia

Namanya Segaluh

Syahdan yang merajai

Sang Dewi Rayungwulan

Sangat marah sekali

Gegabah menghadapi

Sang Banjaransari

Dihentikan bertapanya

Karena berselisih

Akhirnya terjadi perang

(Terjemahan oleh Raharja)

Keterangan yang termuat pada cakepan, ulihan pertama mengungkapkan pertemuan antara Raden Banjaransari dengan gurunya, yaitu Jatiraga, seorang begawan yang sakti dan memiliki kepandaian. Menurut petunjuk Begawan tersebut, untuk mengentaskan permasalahan yang dihadapi, Raden Banjaransari harus melawan musuhnya yang berasal dari Kerajaan Segaluh, sebuah kerajaan jin yang dipimpin oleh seorang ratu bernama Dewi Rayungwulan. Ulihan kedua mengungkapkan kemarahan Dewi Rayungwulan yang ketentramannya terganggu oleh aura yang ditimbulkan dari laku bertapa Raden Banjaransari. Dewi Rayungwulan mendatangi dan menghentikan proses ritual yang dilakukan. Pertemuan dan perselisihan keduanya mengakibatkan terjadinya peperangan. Dalam pemahaman masyarakat Jawa terdapat kesadaran mengenai makrokosmos yang mencakup dimensi fisik dan metafisik (Relin DE, 2017: 48).

Bagian ini dilanjutkan gending berbentuk ladrang tanpa vokal atau pocapan tertentu.

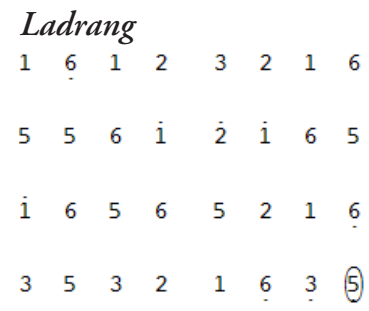


Sajian gending dalam bentuk ladrang merupakan bagian trasisi. Ladrang ini dipergunakan untuk mengolah dinamikanya. Cara pengolahannya dilakukan dengan memainkan irama $I$ yang ditabuh secara soran. Istilah tersebut berasal dari kata 'sora' yang artinya adalah keras. Bagian tersebut tidak memberikan informasi tentang alur cerita yang terjadi karena tidak terdapat lagu vokal karawitan dan cakepannya. Vokal dalam bentuk gerongan disajikan pada bagian terakhir. Bentuknya digolongkan ke dalam bentuk ketawang. Berikut ini adalah cakepan pada bagian yang dimaksudkan.

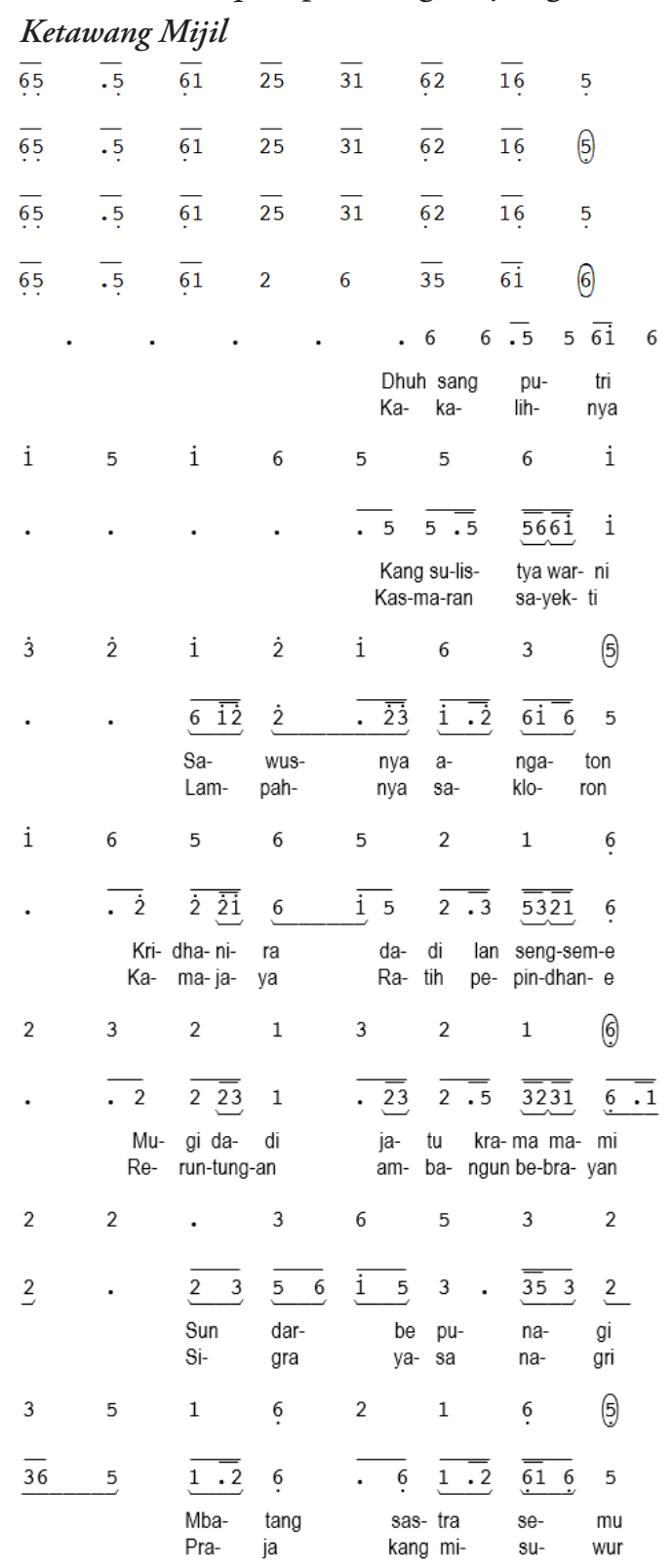

Gending terakhir pada karawitan iringan tari ini berupa gending berbentuk ketawang. Kebiasaan yang berlaku pada mayoritas gending dalam bentuk ini, yaitu peletakan lagu dan keterangannya pada bagian ngelik. Cakepan-nya digubah dalam dua versi yang dilantunkan pada masing-masing ulihan. Berikut ini adalah cakepan lagunya.

Dhuh Sang Putri

Kang sulistya warni

Sawusnya angaton

Kridhanira dadi lan sengseme

Mugi dadi jatukrama mami

Sun darbe punagi

Mbatang sastra semu

Kakalihnya

Kasmaran sayekti

Lampahnya sakloron

Kamajaya Ratih pepindhane

Reruntungan ambangun bebrayan

Sigra yasa nagri

Praja kang misuwur

Terjemahan:

Duh Sang Puteri

Yang cantik rupawan

Setelah memperlihatkan diri

Keterampilan (berperang) menjadi terkesima

Semoga menjadi jodohku

Aku mempunyai permintaan

Menebak teka-teki

Keduanya

Jatuh cinta yang mendalam

Perjalanan keduanya

Kamajaya Ratih ibaratnya

Berdampingan membangun hubungan

Segera mendirikan negara

Kerajaan yang terkemuka

(Terjemahan oleh Raharja)

Bagian yang dilantunkan pada ulihan pertama memuat keterangan tentang perasaan cinta Raden Banjaransari terhadap Dewi Rayungwulan. Sang Pangeran terkesima dengan kecantikan dan ketrampilan Dewi Rayungwulan dalam berperang. Selanjutnya, Raden Banjaransari berniat untuk meminang dan menjadikannya sebagai istrinya. Dewi Rayungwulan akan menerima pinangan apabila Sang Pangeran dapat menebak teka-teki yang diberikan. Ulihan yang kedua menceritakan perasaan kedua figur tersebut. Hubungan yang romantis diibaratkan seperti perasaan cinta Kamajaya dan Dewi Ratih. Hubungan tersebut berujung pada sebuah cita-cita untuk mendirikan negara yang terkemuka. 


\section{Penutup}

Berdasarkan fenomena, permasalahan, solusi yang ditawarkan, dan sejumlah analisis yang disajikan pada bagian pembahasan, dapat ditemukan adanya beberapa kesimpulan sebagai berikut. Kendala ataupun kegagalan untuk memahami sebuah sajian tari melalui karawitan terjadi karena adanya beberapa permasalahan. Pertama, kompleksitas materi yang disajikan melalui unsur tari dan musik pendukungnya sehingga terbatas pada kemampuan otak manusia untuk memahami secara simultan. Kedua, kenyataan yang dihadapi oleh masyarakat yaitu ketidakcukupan bekal yang dimiliki oleh masyarakat untuk mengetahui tema, makna, dan alur cerita pada Lelangen Beksan Banjaransari. Permasalahan tersebut dapat diselesaikan dengan mengetahui estetika garap karawitan dan pengetahuan mengenai bahasa yang dipergunakan. Formula yang dipergunakan untuk mengungkap permasalahan ini dapat diterapkan pada tarian lainnya.

\section{Kepustakaan}

Astuti, B. (2010). Dokumentasi Tari Tradisional. Resital: Jurnal Seni Pertunjukan, 11(1), 59-68.

Grupe, G. (2015). From tacit to verbalized knowledge. Towards a culturally informed musical analysis of Central Javanese karawitan. Periféria: Revista de Recerca i Formació En Antropologia, 20(2), 26-43. https://doi.org/10.5565/ rev/periferia. 496

Harwood, D. L. (2011). Rasa: Affect and Intuition in Javanese Musical Aesthetics. Music Library Association. Notes, 68(1), 78-81. Retrieved from https://search.proquest.com/docview/ 883546798 ? accountid $=38628$

Indrayuda. (2015). Tari Tradisional Dalam Ranah Tari Populer: Kontribusi, Relevansi, Dan Keberlanjutan Budaya. Humanus, Vol XIV(No. 2), 144-151.

Irawan, E., Soedarsono, R. M., \& Simatupang, G. R. L. L. (2014). Karakter Musikal Lagu Gedé Kepesindenan Karawitan Sunda. Resital: Jurnal Seni Pertunjukan, 15(1), 18-31.

Prasetya, H. B., Haryono, T., \& Simatupang, L. L.
(2011). Habitus,Ngêng, dan Estetika Bunyi Mlèsèt dan Nggandul pada Karawitan. Paradigma: Jurnal Kajian Budaya, 1(2), 152-167. Relin DE. (2017). Pementasan Tari Gandrung Dalam Tradisi Petik Laut Di Pantai Muncar, Desa Kedungrejo, Banyuwangi, Jawa Timur (Suatu Kajian Filosofis). MUDRA Jurnal Seni Budaya, 32(1), 41-55.

Saearani, M. F. T. bin, Simatupang, G. L. L., Soedarsono, R. M., \& Kusmayati, A. M. H. (2014). Cultural Transformation Processes in the Current Development of Yogyakarta-Style Classical Dance. International Journal for Innovation Education and Research, 2, 134-141. Retrieved from http://www.ijier.net/assets/ cultural-transformation-processes-in-thecurrent-development-ijier.net-vol-2-4_12.pdf Saepudin, A. (2015). Laras, Surupan, dan Patet dalam Praktik Menabuh Gamelan Salendro. Resital, 16(1), 52-64.

Sinaga, F. S. S. (2016). Musik Trunthung Sebagai Media Ekspresi Masyarakat Warangan. Seminar Antar Bangsa, 161-174. https://doi. org/10.31227/osf.io/wc4vy

Sunardi, C. (2017). Talking about Mode in Malang, East Java. Asian Musican, 48(2), 62-92.

Suyatno, S., Tjokronegoro, H. A., Merthayasa, I. G. N., \& Supanggah, R. (2016). Analysis of Onstage Acoustics Preference of Musicians of Traditional Performance of Javanese Gamelan Based on Normalized Autocorrelation Function. Journal of Engineering and Technological Sciences, 48(5), 571-583. https://doi. org/10.5614/j.eng.technol.sci.2016.48.5.5

Suyoto, Haryono, T., \& Hastanto, S. (2015). Estetika Bawa dalam Karawitan Gaya Surakarta. Resital: Jurnal Seni Pertunjukan, 16(1), 36-51. Widodo. (2015). Laras in Gamelan Music's Plurality. Harmonia: Journal of Arts Research and Education, 15(1), 34-45. https://doi. org/10.15294/harmonia.v15i1.3695

Widodo, W., Ganap, V., \& Soetarno, S. (2017). Laras concept and its triggers: A case study on garap of jineman Uler Kambang. Harmonia: Journal of Arts Research and Education, 17(1), 75. https://doi.org/10.15294/harmonia.v17 i1.10771 